\title{
АДМІНІСТРАТИВНО-ПРАВОВА ХАРАКТЕРИСТИКА ПРОФІЛАКТИКИ ПРАВОПОРУШЕНЬ У СФЕРІ ВЛАСНОСТІ
}

Комарницька I. I.

\section{ВСТУП}

Діяльність органів публічного управління щодо усунення чи мінімізації негативних суспільних тенденцій правовими засобами набуває форми профілактичної діяльності та може стосуватися різних сфер життя суспільства. Однією з них є сфера власності, що охоплює соціальні зв'язки та відносини щодо привласнення і відчуження, користування і розпорядження об'єктами матеріального і нематеріального характеру. Діяльність щодо профілактики адміністративних проступків у цій сфері - це діяльність широкого кола суб'єктів, яка поєднує систему примусових заходів і соціальної допомоги різним представникам суспільства задля коригування соціальної орієнтації та формування мотивації людей до реалізації суспільно корисної діяльності й активізації особистого потенціалу кожного індивіда.

Незважаючи на те, що в Україні є значна кількість суб'єктів профілактики адміністративних правопорушень у сфері власності, кількість таких проступків щороку зростає.

Ефективне здійснення профілактики адміністративних правопорушень у сфері власності потребує чіткого наукового уявлення про систему заходів профілактики цих адміністративних правопорушень, їхні ознаки, особливості тощо. Поряд із цим надзвичайно важливим $€$ розуміння специфіки сучасних заходів профілактики, зумовленість їх конкретним етапом соціально-економічного розвитку держави, здатності змінюватися у процесі еволюційного розвитку відносин власності в державі.

Окремі теоретичні аспекти проблеми профілактики адміністративних правопорушень у сфері власності були предметом дослідження Д. Бахраха, К. Бугайчука, І. Голосніченка, В. Галунька, Т. Зарубицької, В. Колпакова, О. Клюєва, О. Кузьменко, Д. Лук'янця, І. Личенко, Г. Міньковського, Л. Попова, О. Остапенка, 3. Рахліна, В. Рєзвих, А. Трофімчук.

Попри теоретичну та практичну значущість пошуку шляхів удосконалення профілактики адміністративних правопорушень у сфері власності, в науці адміністративного права ці питання недостатньо відображені. 


\section{1. Історіографія дослідження питання профілактики}

\section{адміністративних правопорушень у сфері власності}

Аналіз наукової літератури, вітчизняних і зарубіжних праць з істоpiï, психології, соціології, права є необхідною передумовою всебічного дослідження проблем профілактики адміністративних правопорушень у сфері власності. Пошук шляхів вирішення цих проблем також повинен відбуватися з огляду на дослідження представників цивільного, кримінального права, криміналістики.

Розширення сучасного розуміння профілактики адміністративних правопорушень у сфері власності можливе лише на основі детального опрацювання відповідної історіографічної основи, а комплексність їі наукового дослідження є запорукою отримання об'єктивних і достовірних результатів.

Усю наукову літературу, яка стосується профілактики правопорушень у сфері власності, слід об'єднати у кілька груп, зважаючи на зміст і цільову спрямованість. Можна говорити про існування чотирьох блоків наукових джерел. Перший блок відображає історичні етапи становлення сучасної системи профілактики адміністративних правопорушень у сфері власності, другий - об'єднує юридичну літературу в галузі адміністративного, цивільного, кримінального права, криміналістики тощо. Третій блок представлений літературою соціально-педагогічного, віктимологічного та психологічного характеру, яка стосується забезпечення індивідуальної виховно-профілактичної роботи, попередження аморальних явищ у суспільстві. Четвертий стосується соціально-економічних, ідеологічних, культурних профілактичних заходів, що застосовуються державою ${ }^{1}$

Перший блок джерел пов'язаний із науковим дослідженням зародження і становлення системи профілактики адміністративних правопорушень у сфері власності. Він охоплює праці відомих філософів, мислителів, юристів, котрі досліджували дію заходів попереджувального характеру у протидії незаконній діяльності людиниㄹ. Цей блок представлений також науковою літературою, що відображає еволюцію наукових поглядів на проблему захисту прав і законних інтересів людини, зокрема і щодо попередження правопорушень, систематизацію цих поглядів і наукові джерела, в яких аналізуються процеси створення законодавства профілактичного характеру.

\footnotetext{
1 Личенко І.О. Адміністративно-правовий захист права власності в Україні : дис. ... канд. юрид. наук : 12.00.07. Львів, 2009. С. 64.

2 Адміністративно-правове забезпечення прав і свобод людини та громадянина: навчальний посібник / Ієрусалімова І.О., Ієрусалімов І.О., Павлик П.М., Удовенко Ж.В. Київ : Знання, 2007. С. 23.
} 
До другого блоку історіографічної основи входять наукові праці, в яких здійснено аналіз особливостей, основних напрямів, форм профілактики адміністративних правопорушень у сфері власності, адміністративно-правових засад їх організації та здійснення³. Фактично у цьому блоці доцільно об'єднати джерела адміністративно-правового характеру та наукові праці представників інших галузей права, які доповнюють адміністративно-правову літературу, зважаючи на спорідненість форм і методів профілактики злочинів та адміністративних деліктів, що вчиняються у сфері власності, деталізують специфіку правовідносин у сфері власності, щодо яких здійснюється протиправне посягання, тощо.

Тісний зв'язок наукових джерел 3 адміністративного, кримінального права, криміналістики в одному блоці пояснюється тим, що на етапі ранньої профілактики правопорушень у сфері власності доволі складно розмежувати методи профілактики злочинів та адміністративних деліктів. У науковій літературі на цьому етапі можна говорити лише про попередження антигромадської поведінки взагалі, яка лише згодом може втілитися у кримінальних або деліктних проявах ${ }^{4}$.

Зважаючи на те, що за своєю суттю реалізація заходів профілактики адміністративних правопорушень у сфері власності направлена на адміністративно-правову охорону прав і законних інтересів у сфері власності, важливою історіографічною основою дослідження $€$ значний обсяг наукових джерел, у яких здійснено аналіз адміністративно-правових засобів охорони чи захисту правових можливостей у сфері власності профілактичного характеру 5 .

Третій блок історіографічної основи профілактики адміністративних правопорушень у сфері власності охоплює літературу соціально-педагогічного, віктимологічного та психологічного характеру.

У літературі профілактика розглядається як складова частина будьякої діяльності, спрямована на попередження виникнення і розвитку соціальних проблем і проблем особистості. У такій профілактиці виділяють профілактику аморальних вчинків і профілактику правопорушень ${ }^{6}$.

\footnotetext{
3 Адміністративно-правове забезпечення прав і свобод людини та громадянина: навчальний посібник / Ієрусалімова І.О., Ієрусалімов І.О., Павлик П.М., Удовенко Ж.В. Київ : Знання, 2007. С. 24.

4 Калюжний Р.А., Заєць О.М. Попередження кримінальних правопорушень у сфері страхування : монографія. Луганськ : ЛДУВС ім. Е.О. Дідоренка, 2014. С. 55.

5 Личенко I.О. Адміністративно-правовий захист права власності в Україні : дис. ... канд. юрид. наук : 12.00.07. Львів, 2009. С. 77.

6 Мотунова Н.В. Сутність поняття профілактики правопорушень серед неповнолітніх. Науковий вісник Ужгородського наџіонального університету. Серія: Педагогіка. Соціальна робота. 2014. Вип. 31. С. 104.
} 
Наукова література, представлена в цьому блоці, є основою попередження правопорушень через соціально-педагогічну роботу серед осіб, щодо яких на підставі певних психологічних чи соціальних характеристик можуть вчинятися правопорушення. Зміст історіографічної основи цього блоку охоплює літературу, присвячену діяльності соціальних інституцій щодо соціальної адаптації, виховання, реабілітації, психологічної допомоги людям тощо.

Соціально-педагогічна віктимологія вивчає на міждисциплінарному рівні різноманітні категорії реальних і потенційних жертв несприятливих умов соціалізації, досліджує чинники, які створюють передумови для дефіциту можливостей повноцінного фізичного, духовного, емоційного, культурного, соціального розвитку і самореалізації їх; розробляє методики, технології, стратегії та тактики соціально-педагогічної діяльності, спрямовані, з одного боку, на профілактику, мінімізацію, компенсацію і корекцію тих обставин, через які людина стає жертвою несприятливих умов соціалізації, а 3 іншого - на формування доцільного рефлексу цілі на основі позитивних задатків людини-жертви та ії̈ внутрішньо-інтенційної спрямованості.

Дослідження психологічних станів і визначення особливостей поведінки особи здатні слугувати важливою основою діяльності суб' єктів профілактики адміністративних правопорушень у сфері власності.

Девіантна поведінка - це дії, що не відповідають офіційно встановленим або фактично сформованим у певному суспільстві (соціальній групі) нормам і призводить порушника до ізоляції, лікування, виправлення або покарання.

Здійснюючи індивідуальну профілактику адміністративних правопорушень, суб'єкт, котрий іiі реалізує, насамперед визначає можливі причини асоціальної поведінки особи: спадкові передумови, певні характерологічні та патохарактерологічні особливості, дефекти раннього виховання, залучення в асоціальні групи тощо 7 . Їх розуміння неможливе без володіння базовими знаннями із психології.

Останнім блоком наукової літератури, що становить основу дослідження проблем профілактики адміністративних правопорушень у сфері власності, є сукупність праць соціально-економічного, ідеологічного, культурного характеру, які формують розуміння важливості існування гуманістичних основ профілактики будь-якої протиправної діяльності.

Окреслений зміст наукової літератури історіографічної основи дослідження профілактики адміністративних правопорушень у сфері

\footnotetext{
7 Кікалішвілі М.В. Девіантна поведінка: поняття та ознаки. Вісник Академї адвокатури України. 2011. Число 3. С. 109-122.
} 
власності дає змогу пізнати складну природу протиправної поведінки особи, різноманіття iї причин та умов, врахувати особливості психологічного стану особи, який спонукає іiі вчинити правопорушення, зрозуміти сукупність соціальних, економічних чинників, що зумовлюють адміністративні правопорушення у сфері власності, та визначити сукупність правових, соціально-педагогічних, соціально-економічних, ідеологічних, культурних засобів, які здатні забезпечити профілактику таких деліктів.

\section{2. Поняття й особливості профілактики адміністративних правопорушень у сфері власності}

Профілактика адміністративних правопорушень у сфері власності є важливим напрямом протидії правопорушенням, які посягають на правові можливості громадян, і забезпечення реалізації прав і законних інтересів осіб щодо володіння, користування та розпорядження майном. Комплексне дослідження поняття й особливостей профілактики адміністративних правопорушень у сфері власності $є$ важливою передумовою пошуку шляхів удосконалення цілого адміністративно-правового механізму охорони прав і законних інтересів громадян у сфері власності та розв’язання наявних у цій сфері проблем.

Профілактичні заходи сприяють не тільки виявленню правопорушень, а і встановленню й усуненню причин і умов, що їм сприяють, допомагають утримати особу від їхнього вчинення ${ }^{8}$.

Профілактика адміністративних правопорушень у сфері власності орієнтована на формування законослухняної поведінки громадян i посадових осіб, зменшення заподіяної правопорушеннями шкоди, усунення причин і умов їх вчинення, поширення соціально прийнятних моделей поведінки через правове виховання та правову пропаганду, соціальну адаптацію громадян, які належать до «групи ризику».

Доволі поширеним у науці адміністративного права $є$ трактування профілактики адміністративних правопорушень як сукупності державних, суспільних та інших заходів.

Безумовно, спрямованими на профілактику адміністративних правопорушень $є$ як сукупність наявних профілактичних заходів загалом, так і діяльність окремих суб'єктів профілактики адміністративних правопорушень зокрема 9 .

\footnotetext{
8 Клюєв О. Розмежування запобіжної і профілактичної діяльності органів внутрішніх справ. Право Украӥни. 2005. № 3. С. 98.

9 Гридасов Ю.В. Адміністративно-правові засоби захисту права власності в Україні : автореф. дис. ... канд. юрид. наук : 12.00.07. Ірпінь, 2009. С. 9.
} 
Оскільки поняття «захід» $\mathrm{i}$ «діяльність» співвідносяться як загальне та часткове, а формування дефініції цього поняття повинно будуватися на розумінні його комплексної природи, враховувати існування широкого спектру рівнів, форм і видів профілактики адміністративних правопорушень, слід погодитися, що профілактика адміністративних правопорушень - це цілісний комплекс заходів держави, органів державної влади та місцевого самоврядування, їх посадових осіб, громадських організацій та окремих громадян.

Профілактична діяльність охоплює широкий перелік заходів, які нейтралізують правопорушення, компенсаційні заходи, заходи, що запобігають виникненню негативних обставин, i ті, які їх ліквідують ${ }^{10}$.

Воно проявляється через застосування заходів щодо виявлення й усунення причин та умов окремих адміністративних правопорушень у сфері власності, встановлення осіб, схильних до протиправної діяльності, вплив на таких осіб з метою усунення намірів щодо порушення чинного законодавства з приводу володіння, користування та розпорядження майном, виявлення осіб, котрі готуються вчинити адміністративні проступки у сфері власності, перешкоджання продовженню розпочатого правопорушення, усунення причин та умов вчинення адміністративних деліктів.

Таким чином, поняття запобігання адміністративним правопорушенням у сфері власності охоплює заходи щодо попередження, припинення адміністративних проступків і виявлення причин та умов для їх вчинення.

Попередження адміністративних правопорушень досягається шляхом застосування актів адміністративного попередження, які охоплюють перевірку документів окремих осіб, особистий огляд і огляд речей, відвідування підприємств, установ і організацій, адміністративний нагляд за особами, звільненими з місць позбавлення волі, впровадження обмежень щодо доступу до окремих об'єктів, входу чи проїзду на окремі ділянки місцевості, внесення подань до державних органів, підприємств, установ та організацій, посадовим особам про необхідність усунення причин та умов, що сприяли вчиненню правопорушення, тощо ${ }^{11}$. Основною метою цих заходів є встановлення осіб, які готуються вчинити посягання на право власності, та попередити вчинення цього діяння.

10 Клюєв О.М. Сутність та загальна характеристика профілактичної діяльності на місцевому рівні. Форум права. 2006. № 2. С. 76-79.

11 Чабан В.П. Акти адміністративного примусу в діяльності міліції України : дис. ... канд. юрид. наук : 12.00.07. Київ, 2001. 178 с. 
Заходи адміністративного припинення охоплюють передбачені законом засоби впливу, спрямовані на примусове переривання (припинення) діянь, що мають ознаки адміністративного правопорушення, недопущення шкідливих наслідків протиправної поведінки, забезпечення провадження у справі про адміністративне правопорушення і притягнення винного до адміністративної відповідальності. Вони зафіксовані у ст. 260 КУпАП та інших нормативно-правових актах, спрямовані на створення перешкод щодо продовження вже розпочатого проступку, втручання у протиправну ситуацію з метою ії переривання, можуть мати економічний характер чи бути спрямованими на реалізацію особистого, фізичного впливу на правопорушника ${ }^{12}$.

Заходи припинення адміністративних правопорушень у сфері власності охоплюють вимогу припинити правопорушення, адміністративне затримання особи, вилучення речей і документів, зупинку або припинення робіт тощо.

Заходи щодо виявлення причин та умов протиправної діяльності пов'язані з аналізом низки чинників: психологічних, соціальних і біологічних. Тобто визначається і нейтралізується своєрідний психобіосоціальний фон цих правопорушень.

Уся ця система охоплює комплекс не лише виховних і роз'яснювальних заходів, але й активну протидію незаконній діяльності через психологічний або фізичний вплив державних органів і громадських об'єднань на певних осіб із метою спонукати, примусити їх виконувати правові норми ${ }^{13}$.

Наведена система заходів профілактики адміністративних правопорушень у сфері власності здійснюється різними адміністративно-правовими методами. Основними 3 них $є$ переконання й адміністративно-правовий примус.

Застосування адміністративно-правового примусу зумовлене недосягненням необхідних результатів внаслідок використання методу переконання. Зберігається пріоритет заходів переконання над адміністративно-примусовими заходами профілактики адміністративних правопорушень у сфері власності. Їх застосування є першочерговим.

Якщо існує небезпека посилення загрози настання шкідливих наслідків, досягнення бажаних результатів шляхом застосування заходів

12 Кодекс України про адміністративні правопорушення. URL: https://zakon.rada.gov.ua/ laws/show/80731-10.

13 Профілактика злочинів на транспорті : навчальний посібник / О.А. Антоненко, С.О. Баранов, А.І. Берлач та ін. Одеса : Фенікс, 2011. 460 с. 
переконання стає неможливим чи неефективним, суб'єкти профілактики можуть застосувати адміністративно-примусові заходи, спрямовані на запобігання вчинення проступку та настання шкідливих наслідків.

Примусово-обов'язковий, державно-владний та оперативний характер застосування заходів профілактики зумовлений потребою негайного втручання, припинення адміністративного правопорушення у сфері власності, відвернення шкідливих наслідків, завдання шкоди майну, законним правам власників.

Застосування заходів виховних та адміністративно-примусових заходів профілактики адміністративних правопорушень у сфері власності потребує належного планування.

Планування реалізації вищезазначених профілактичних заходів пов'язане з розробкою планів, спрямованих на попередження різних правопорушень аж до викорінення причин і умов, що сприяють формуванню протиправної поведінки. Комплексне планування профілактики правопорушень передбачає чітке визначення принципів, цілей, об'єктів профілактики, суб'єктів іiї здійснення та способів взаємозв'язку і взаємодії між учасниками ${ }^{14}$.

3 огляду на зазначене вважаємо, що планування та реалізація заходів профілактики адміністративних правопорушень у сфері власності здійснюється на принципах законності, гуманізму, наукової обгрунтованості, плановості, економічної та юридичної обгрунтованості, недоторканності приватного життя та майнових прав особи, взаємодії суб' єктів профілактики, пріоритету заходів переконання над адміністративно-примусовими заходами профілактики адміністративних правопорушень у сфері власності.

Планування профілактики адміністративних правопорушень у сфері власності передбачає розробку поточних, спеціальних, тактичних та інших планів. Всі вони повинні відповідати вимогам наукової обгрунтованості, базуватися на достовірній і повній інформації, що використовується, й аналізі оперативної обстановки на відповідній території, забезпечувати ефективну взаємодію підрозділів і служб, наділених повноваженнями у цій сфері, визначати способи контролю й оцінки результатів планування та засоби реагування за їх результатами. Планування профілактики адміністративних правопорушень у сфері власності потребує розробки альтернативних варіантів плану реалізації профілактичних заходів, чіткого визначення способів управління

\footnotetext{
14 Личенко І.О. Адміністративно-правовий захист права власності в Україні : дис. ... канд. юрид. наук : 12.00.07. Львів, 2009. 264 с.
} 
реалізацією. У кожному окремому випадку встановлюється масштаб заходів, які будуть реалізовуватися, визначається термін їх здійснення, коло виконавців, необхідний обсяг коштів, матеріальних ресурсів, способів контролю за ефективністю профілактичної діяльності ${ }^{15}$.

Таким чином, профілактика адміністративних правопорушень це методологічно складне суспільне явище, яке охоплює багаторівневу систему заходів, що проводяться державними, недержавними органами й установами, громадськими формуваннями й окремими громадянами 3 метою виявлення причин та умов вчинення адміністративних правопорушень для мінімізації або нейтралізації впливу діянь, які породжують правопорушення, пошуку шляхів, засобів ефективного впливу на потенційного правопорушника. Вона $є$ комплексною категорією, що об'єднує систему заходів, спрямованих на забезпечення недоторканості прав особи у сфері власності, запобігання їх порушенню, реалізацію закріпленої у чинних правових актах можливості кожного громадянина України володіти, користуватися та розпоряджатися майном ${ }^{16}$.

Можна стверджувати, що профілактика адміністративних правопорушень у сфері власності - це інтегрований цілісний комплекс заходів соціального, спеціального та індивідуального характеру, який здійснюється державою, органами державної влади та місцевого самоврядування, їх посадовими особами, громадськими організаціями й окремими громадянами з метою виявлення причин та умов вчинення адміністративних правопорушень, що посягають на право власності, усунення чинників, які детермінують протиправну діяльність особи щодо порушення правових можливостей особи володіти, користуватися та розпоряджатися майном, попереджувального впливу на осіб, схильних до протиправної поведінки, запобігання правопорушенням у цій сфері.

Діяльність у сфері профілактики адміністративних правопорушень у сфері власності має важливе значення у протидії цим адміністративним правопорушенням. Вона є різносторонньою, базується на можливості застосування широкого арсеналу заходів профілактики ${ }^{17}$.

\footnotetext{
15 Лиховид В.І. Профілактика як дійсний засіб попередження росту злочинності. Вісник Запорізького юридичного інституту. 2001. № 3. С. 199-203.

16 Профілактика злочинів на транспорті : навчальний посібник / О.А. Антоненко, С.О. Баранов, А.І. Берлач та ін. Одеса : Фенікс, 2011. 460 с.

17 Личенко І.О. Адміністративна відповідальність посадових осіб органів місцевого самоврядування : навчальний посібник. Львів: Львівський державний університет внутрішніх справ, 2011. С. 99.
} 
Оптимальний перелік таких заходів визначається у кожному окремому випадку та зумовлюється потребами профілактичного впливу й особливостями суб' єкта, уповноваженого застосувати ці заходи ${ }^{18}$.

Сучасний стан профілактики адміністративних правопорушень у сфері власності відзначається цілою низкою недоліків. Назріла потреба удосконалення нормативно-правової бази з питань правоохоронної діяльності та профілактики правопорушень.

\section{3. Правове забезпечення профілактики адміністративних правопорушень, які посягають на право власності}

Реалізація заходів профілактики адміністративних правопорушень у сфері власності потребує їх належного правового забезпечення.

Пояснення терміна «правове забезпечення» відзначається відсутністю єдиного визначення, виробленого на доктринальному рівні.

Термін «забезпечувати» в науковій літературі тлумачиться як «створювати надійні умови для здійснення чого-небудь; гарантувати щось» ${ }^{19}$. Натомість поняття «правове забезпечення» визначають як передбачені законом або договором спеціальні заходи, сукупність статичного та динамічного компонентів цієї категорії, що об'єднує гарантії реалізації й охорони прав громадян і діяльність органів державної влади зі створення умов, необхідних для реалізації громадянами своїх прав, регламентовану адміністративно-правовими нормами діяльність суб'єктів державно-владних повноважень, і встановлену адміністративно-правовими нормами систему гарантій належного функціонування цих суб' єктів ${ }^{20}$.

3 огляду на таке різноманіття підходів до визначення суті поняття «правове забезпечення» можна стверджувати, що «правове забезпечення профілактичної діяльності» за своїм змістом є методологічно складним суспільним явищем, яке об'єднує різні прояви та рівні, на яких реалізується правовий вплив.

Повнота регулювання в системі адміністративно-правового забезпечення досягається через тісний зв'язок специфічної нормативної частини правового впливу та системи гарантій функціонування суб'єктів правозастосування.

\footnotetext{
18 Личенко І.О. Адміністративна відповідальність посадових осіб органів місцевого самоврядування : навчальний посібник. Львів : Львівський державний університет внутрішніх справ, 2011. С. 100.

19 Клюєв О. Розмежування запобіжної і профілактичної діяльності органів внутрішніх справ. Право Украӥни. 2005. № 3. С. 99.

20 Профілактика злочинів на транспорті: навчальний посібник / О.А. Антоненко, С.О. Баранов, А.І. Берлач та ін. Одеса : Фенікс, 2011. С. 201.
} 
Таким чином, правове забезпечення профілактичної діяльності проявляється через систему правових норм і законодавчих актів, зміст яких стосується профілактики адміністративних правопорушень, і формування системи адміністративно-правових гарантій належного функціонування системи суб'єктів профілактичної діяльності.

Адміністративно-правове забезпечення профілактичної діяльності передбачає регулювання за допомогою норм адміністративного права цілого комплексу запобіжних заходів, впровадження яких нейтралізує протиправний вплив адміністративних правопорушень і забезпечує можливість поліпшення якості суспільних відносин ${ }^{21}$.

Правове забезпечення профілактики адміністративних правопорушень, що посягають на право власності, передбачає регулювання за допомогою норм адміністративного права суспільних відносин між органами державної влади та місцевого самоврядування, їх посадовими особами, громадськими організаціями й окремими громадянами щодо виявлення причин та умов вчинення адміністративних правопорушень, які посягають на право власності, усунення чинників, що детермінують протиправну діяльність особи щодо порушення правових можливостей володіти, користуватися та розпоряджатися майном, попереджувального впливу на осіб, схильних до протиправної поведінки, запобігання правопорушенням у цій сфері.

Усю систему нормативно-правових актів, норми яких є правовою основою профілактики адміністративних правопорушень у сфері власності, доцільно поділити на два блоки. Зміст правових норм першого блоку таких актів $є$ загальним, він $є$ правовим забезпеченням профілактики різних проявів протиправної діяльності й адміністративних правопорушень у сфері власності зокрема.

До цих нормативно-правових актів доцільно віднести Указ Президента України від 18 лютого 2002 р. № 143 «Про заходи щодо дальшого зміцнення правопорядку, охорони прав і свобод громадян», Указ Президента України від 27 жовтня 2009 р. № 870 «Про рішення Ради національної безпеки і оборони України від 11 вересня 2009 р. «Про стан злочинності у державі та координацію діяльності органів державної влади у протидії злочинним проявам та корупції», розпорядження Кабінету Міністрів України від 30 листопада 2011 р. № 1209-р «Про схвалення Концепції реалізації державної політики у сфері профілактики правопорушень на період до 2015 р.»².

21 Личенко І.О. Адміністративно-правовий захист права власності в Україні : дис. ... канд. юрид. наук : 12.00.07. Львів, 2009. 264 с.

22 Гридасов Ю.В. Адміністративно-правові засоби захисту права власності в Україні : автореф. дис. ... канд. юрид. наук : 12.00.07. Ірпінь, 2009. 20 с. 
Особливе значення серед вищезазначених нормативно-правових актів має розпорядження Кабінету Міністрів України від 30 листопада 2011 р. № 1209-р «Про схвалення Концепції реалізації державної політики у сфері профілактики правопорушень на період до 2015 р.», оскільки його зміст спрямований на підвищення ефективності профілактичної діяльності, стосується не лише основних проблеми організації профілактики правопорушень, але й визначає конкретні заходи щодо їх подолання.

Основною характеристикою цих нормативно-правових актів $є$ їх широкий спектр дії, спрямованість на реалізацію системи правових, організаційних, виховних заходів щодо виявлення, усунення та нейтралізації причин адміністративних правопорушень і умов їх вчинення, формування правомірної поведінки особи та забезпечення комплексного підходу до вирішення проблеми протидії адміністративним правопорушенням.

Другий блок нормативно-правових актів характеризується спрямованістю на профілактику саме адміністративних правопорушень у сфері власності.

До таких нормативно-правових актів можна віднести Концепцію розвитку національної системи правової охорони інтелектуальної власності, затверджену розпорядженням Кабінету Міністрів України від 13 червня 2002 р. № 321-р, постанову Кабінету Міністрів України від 10 серпня 1993 р. № 615 «Про заходи щодо вдосконалення охорони об'єктів державної та інших форм власності», Указ Президента України від 26 березня 2009 р. № 191/2009 «Про додаткові заходи щодо посилення захисту права власності» та ін. ${ }^{23}$.

До цього блоку також входить ціла низка нормативно-правових актів MBC України, які продовжують діяти до формування МВС України та Національною поліцією нового законодавства у сфері профілактики адміністративних правопорушень: наказ МВС України від 25 листопада 2003 р. № 1433 «Про організацію службової діяльності міліції охорони Державної служби охорони при МВС України», наказ МВС України від 25 листопада 2003 р. № 1432 «Про організацію службової діяльності спеціальних підрозділів міліції охорони «Титан», «Інструкція із здійснення підрозділами ДСО заходів майнової та особистої безпеки громадян із використанням технічних засобів охорони», затвердженої наказом МВС України від 25 листопада 2003 р. № 1429, та ін.

23 Гридасов Ю.В. Адміністративно-правові засоби захисту права власності в Україні : автореф. дис. ... канд. юрид. наук : 12.00.07. Ірпінь, 2009. 20 с. 
Важливим є той факт, що на місцевому рівні надзвичайно мало нормативно-правових актів, норми яких стосуються профілактики адміністративних правопорушень у сфері власності. Особливо гострою $\epsilon$ необхідність формування правового забезпечення координації діяльності органів державної влади й органів місцевого самоврядування щодо попередження правопорушень із приводу володіння, користування і розпорядження майном.

Нормативне закріплення правового статусу таких органів сприятиме взаємному інформуванню органів місцевого самоврядування й органів внутрішніх справ у процесі здійснення їх функцій про причини й умови, що сприяють правопорушенням щодо права власності, виявлення, аналізу й оцінки фактів, детермінуючих протиправну поведінку, осіб, поведінка котрих свідчить про реальну можливість вчинення посягань на право власності, розробки проектів державних програм боротьби з правопорушеннями, які посягають на право власності, пропозицій із питань їх загальної та індивідуальної профілактики, запобігання найбільш поширеним видам цих правопорушень ${ }^{24}$.

Необхідною умовою належного правового забезпечення профілактичної діяльності щодо адміністративних правопорушень у сфері власності є формування юридичних гарантій належного функціонування системи суб' єктів профілактичної діяльності.

Ці гарантії є спеціально встановленими законом засобами забезпечення правомірності поведінки суб'єктів правовідносин, їх прав і свобод.

Ці гарантії можуть бути трьох видів: контрольно-наглядові, організаційно-процедурні та юрисдикційні ${ }^{25}$. Зміст кожного з видів гарантій правового забезпечення профілактичної діяльності створює стійку систему (норм права, правозастосовної діяльності, індивідуальних юридичних актів), що дають можливість органам державної влади, місцевого самоврядування, їх посадовим особам, громадським організаціям та окремим громадянам здійснювати виявлення причин та умов вчинення адміністративних правопорушень, які посягають на право власності, забезпечувати усунення чинників, що детермінують протиправну діяльність особи щодо порушення правових можливостей володіти, користуватися та розпоряджатися майном, здійснювати

24 Личенко І.О. Адміністративно-правовий захист права власності в Україні : дис. ... канд. юрид. наук : 12.00.07. Львів, 2009. 264 с.

25 Клюєв О. Розмежування запобіжної і профілактичної діяльності органів внутрішніх справ. Право Украӥни. 2005. № 3. С. 98-105 
попереджувальний вплив на осіб, схильних до протиправної поведінки, запобігання правопорушенням у цій сфері ${ }^{26}$.

Таким чином, адміністративно-правове забезпечення профілактичної діяльності $є$ інтегрованою системою інституційних засобів забезпечення захисту прав, свобод і законних інтересів людини та громадянина у сфері власності від незаконних посягань, спрямованих на зниження рівня правопорушень, виявлення, вивчення, усунення умов, причин їх вчинення, координацію діяльності суб'єктів профілактики правопорушень, підвищення рівня правової культури громадян.

\section{ВИСНОВКИ}

Вся наукова література, яка стосується профілактики правопорушень, може бути представлена чотирма блоками наукових джерел. Перший блок відображає історичні етапи становлення сучасної системи профілактики адміністративних правопорушень у сфері власності, другий об'єднує юридичну літературу в галузі адміністративного, цивільного, кримінального права, криміналістики тощо. Третій блок представлений літературою соціально-педагогічного, віктимологічного та психологічного характеру щодо попередження аморальних явищ у суспільстві. Четвертий стосується соціально-економічних, ідеологічних, культурних заходів, які застосовуються.

Профілактика адміністративних правопорушень у сфері власності - це цілісний комплекс заходів соціального, спеціального та індивідуального характеру, що здійснюється державою, органами державної влади та місцевого самоврядування, їх посадовими особами, громадськими організаціями й окремими громадянами 3 метою виявлення причин та умов вчинення адміністративних правопорушень, які посягають на право власності, усунення чинників, що детермінують протиправну діяльність особи у сфері власності та запобігання правопорушенням у цій сфері.

Дослідження профілактики адміністративних правопорушень у сфері власності сприяло виявленню особливостей діяльності щодо iii реалізації. Діяльність щодо профілактики адміністративних правопорушень у сфері власності є різносторонньою, і це зумовлено різноманіттям суспільних відносин, у яких може проявлятися протиправна діяльність, характеризується багаторівневістю та різноманіттям

\footnotetext{
26 Личенко І.О. Адміністративна відповідальність посадових осіб органів місцевого самоврядування: навчальний посібник. Львів: Львівський державний університет внутрішніх справ, 2011. 183 с
} 
видових проявів заходів профілактичного впливу, реалізується значним колом суб' єктів, базується на можливості застосування широкого арсеналу заходів виховного й адміністративно-примусового характеру, потребує ретельного попереднього планування, завчасного визначення способів управління іiі реалізацією.

\section{АНОТАЦІЯ}

Адміністративне право на сучасному етапі розвитку перебуває в пошуках нових наукових підходів щодо характеристики правовідносин у сфері власності та пов'язане із захистом прав і законних інтересів громадян країни. Слід зазначити, що питання, пов'язані зі здійсненням профілактики правопорушень у сфері власності, вже багато років турбують вчених-юристів, правоохоронців-практиків і громадськість. Трансформаційні процеси, які напряму пов'язані із реформуванням багатьох сфер суспільного життя, що регулюють відносини, супроводжуються загостренням багатьох соціальних проблем, які негативно впливають на розвиток суспільних відносин і сприяють вчиненню правопорушень у сфері власності. Профілактичні заходи сприяють виявленню правопорушень і встановленню й усуненню причин та умов, що їм сприяють, допомагають утримати від їх вчинення. Сьогодні назріла нагальна потреба щодо удосконалення профілактики правопорушень; підвищення вимог щодо роботи зі зверненнями громадян, забезпечення реагування на порушення прав і свобод людини; визначення критеріїв оцінки роботи правоохоронних органів із профілактики правопорушень; активізації участі громадян у забезпеченні правопорядку; забезпечення протидії правопорушенням і профілактики протиправної дії; вдосконалення інформаційного забезпечення профілактики правопорушень.

Саме тому відбувається бурхливий розвиток законодавства щодо правопорушень, які вчиняються у сфері власності, виникнення нових правових інститутів і методів правового регулювання у цій сфері та їх профілактики.

\section{ЛІТЕРАТУРА}

1. Гридасов Ю.В. Адміністративно-правові засоби захисту права власності в Україні : автореф. дис. ... канд. юрид. наук : 12.00.07. Ірпінь, 2009. $20 \mathrm{c}$.

2. Адміністративно-правове забезпечення прав і свобод людини та громадянина : навчальний посібник / Ієрусалімова I.O., Ієрусалімов I.О., Павлик П.М., Удовенко Ж.В. Киъв : Знання, 2007. 223 с. 
3. Калюжний Р.А., Заєць О.М. Попередження кримінальних правопорушень у сфері страхування : монографія. Луганськ : ЛДУВС ім. Е.О. Дідоренка, 2014. 216 с.

4. Кікалішвілі М. В. Девіантна поведінка: поняття та ознаки. Вісник Академії адвокатури України. 2011. Число 3. С. 109-122.

5. Клюєв О.М. Сутність та загальна характеристика профілактичної діяльності на місцевому рівні. Форум права. 2006. № 2. С.76-79.

6. Клюєв О. Розмежування запобіжної і профілактичної діяльності органів внутрішніх справ. Право Украӥни. 2005. № 3. С. 98-105.

7. Кодекс України про адміністративні правопорушення. URL: https://zakon.rada.gov.ua/laws/show/80731-10.

8. Профілактика злочинів на транспорті : навчальний посібник / О.А. Антоненко, С.О. Баранов, А.І. Берлач та ін. Одеса : Фенікс, 2011.460 с.

9. Лиховид В.І. Профілактика як дійсний засіб попередження росту злочинності. Вісник Запорізького юридичного інституту. 2001. № 3. C. 199-203.

10. Личенко I.O. Адміністративна відповідальність посадових осіб органів місцевого самоврядування : навчальний посібник. Львів : Львівський державний університет внутрішніх справ, 2011. 183 с.

11. Личенко I.О. Адміністративно-правовий захист права власності в Україні : дис. ... канд. юрид. наук : 12.00.07. Львів, 2009. 264 с.

12. Мотунова Н.В. Сутність поняття профілактики правопорушень серед неповнолітніх. Науковий вісник Ужгородського національного університету. Серія: Педагогіка. Соціальна робота. 2014. Вип. 31. C. 104.

13. Чабан В.П. Акти адміністративного примусу в діяльності міліції України : дис. ... канд. юрид. наук : 12.00.07. Київ, 2001. 178 с.

\section{Information about author:}

Komarnytska I. I., Candidate of Juridical Sciences, Assistant of the Department of Constitutional and International Law Institute of Jurisprudence, Psychology and Innovative Education of the Lviv Polytechnic National University 1/3, Knyaz Roman str., Lviv, Ukraine

DOI https://doi.org/10.30525/978-9934-588-43-3/2.10 